\title{
Penyusunan Penilaian Kinerja Berbasis Kompetensi di Rumah Sakit XXX
}

Raditya Hernawa, Ferdinandus Hindiarto dan Lucia Tresni

Fakultas Psikologi, Kampus III Universitas Sanata Dharma, Paingan, Maguwoharjo, Depok, Sleman. Yogyakarta, Fakultas Psikologi Universitas Katolik Sugijapranata, Jl.Pawiyatan Luhur IV No.1 Bendan Dhuwur Semarang. rhernawa@yahoo.com

\begin{abstract}
This study discusses the development of performance appraisal in XXX hospital. Currently, many employees are dissatisfied with the current performance appraisal tool because it is lack of objectivity. There is no feedback to employees and besides that performance appraisal is not relevant to the needs of hospital. To increase the objectivity of the performance appraisal tool, and maximize the performance appraisal objectiveness, the present study designed and developed competency base performance appraisal. This research is a qualitative research method by used interview data collection method. Competency-Based Performance Appraisal tested on cashier position. The results showed that the aspect of relevance, sensitivity, reliability and acceptability of new competencybased performance appraisal was better than the old performance appraisal. The implication will disccuss further.
\end{abstract}

Keywords: Competency, Performance Appraisal

\begin{abstract}
ABSTRAK
Penelitian ini membahas tentang penyusunan Penilaian kinerja berbasis kompetensi di Rumah Sakit XXX. Selama ini karyawan tidak puas terhadap penilaian kinerja yang digunakan dikarenakan penilaian kinerja dinilai kurang obyektif, tidak ada umpan balik untuk karyawan selain itu penilaian kinerja yang digunakan saat ini sudah tidak sesuai lagi dengan kebutuhan kompetensi perusahaan. Dalam upaya meningkatkan obyektifitas alat penilaian kinerja, dan memaksimalkan tujuan penilaian kinerja maka dirancang penilaian kinerja berbasis kompetensi. Penelitian ini merupakan penelitian kualitatif dengan menggunakan metode pengumpulan data wawancara. Penilaian Kinerja Berbasis Kompetensi diujicobakan pada jabatan kasir bagian keuangan. Hasil penelitian ini menunjukkan bahwa dari aspek relevansi, sensitivitas, reliabilitas dan penerimaan penilaian kinerja berbasis kompetensi lebih baik dibandingan penilaian kinerja yang digunakan selama ini.
\end{abstract}

Kata Kunci: Penilaian kinerja, kompetensi 


\section{PENDAHULUAN}

Rumah Sakit XXX merupakan sebuah Rumah Sakit swasta yang berlokasi di Jawa Tengah. Berbagai prestasi dalam dunia medis telah berhasil dicapainya. Prestasi ini dapat terwujud tidak lepas karena perhatian RS terhadap pengembangan kompetensi yang dimilikinya.

Manajemen RS.XXX meyadari akan pentingnya menjaga dan mengembangkan kualitas Sumber Daya Manusia. Keseriusan dalam upaya meningkatkan kompetensi sumber daya manusianya dituangkan dalam pernyataan misi, kebijakan mutu, ISO 9001:2008 dan penerapan system pengelolaan SDM berbasis kompetensi.

Sistem pengelolaan SDM hanya dapat berhasil dengan baik jika diterapkan secara konsisten dan menyeluruh, sistem tidak dapat diterapkan secara acak dan parsial tapi sistem harus terintegrasi satu sama lain(Gaspersz, 2007). Salah satu bidang yang belum mengacu pada sistem manajemen berbasis kompetensi adalah bidang penilaian kinerja.

Berdasarkan wawancara yang telah dilakukan terhadap beberapa karyawan bagian keuangan, dapat diketahui bahwa karyawan meragukan keakuratan hasil penilaian kinerja yang telah digunakan, karyawan menilai bahwa penilaian kinerja yang digunakan saat ini subyektif. Selain itu faktor kedekatan antara penilai dengan yang dinilai diduga juga mempengaruhi hasil penilaian. Terungkap juga bahwa hasil penilaian tidak dikomunikasikan dengan karyawan sehingga karyawan tidak mengetahui pencapaiannya.

Berdasarkan wawancara yang telah dilakukan dengan Kepala Bagian Rekrutmen dan Pengembangan SDM serta wawancara dengan Officer In Charge (OIC) Finance dapat diketahui bahwa aspek-aspek dalam penilaian kinerja yang saat ini digunakan memiliki arti yang terlalu luas, kurang mampu memberi gambaran secara spesifik tentang pencapaian kinerja karyawan, penilaian kinerja dianggap kurang mampu menyajikan data teknis pekerjaan secara jelas, penilaian kinerja lebih banyak mengungkap soft skill saja.

Penilaian kinerja di RS. XXX secara rutin berjalan setiap 6 bulan sekali. Aspek-aspek penilaian yang digunakan sudah tidak sesuai dengan kompetensi yang telah ditetapkan oleh perusahaan sehingga penilaian kinerja tidak dapat menggambarkan kesenjangan antara tuntutan perusahaan dengan kinerja yang telah dicapai karyawan. Humman Resource Department (HRD) sebagai bagian yang mengelola sumber daya manusia akan mengalami kesulitan dalam mengambil keputusan dan menentukan kebijakan-kebijakan yang tepat sasaran susuai dengan tujuan penilaian kinerja itu sendiri.

Dari hasil analisa awal tersebut, peneliti dapat menyimpulkan beberapa permasalahan sebagai berikut:

1. Karyawan tidak puas terhadap alat penilaian kinerja yang digunakan saat ini dikarenakan penilaian yang sekarang dinilai oleh karyawan subyektif.

2. Penilaian Kinerja yang sekarang tidak ada umpan balik bagi karyawan sehingga karyawan tidak dapat mengetahui dan memperbaiki kekurangannya.

3. Aspek penilaian kinerja yang digunakan saat ini masih terlalu umum, tidak spesifik dan sudah tidak sesuai lagi dengan kebutuhan kompetensi perusahaan sehingga sulit bagi atasan dan HRD untuk membuat program pengembangan dan pelatihan karyawan.

Jika permasalahan di atas tersebut tidak ditanggani dengan baik maka diprediksikan manajemen RS. XXX akan mengalami kesulitan untuk mengambil keputusan dan menentukan kebijakan-kebijakan strategis yang tepat sasaran terkait dengan tujuan penilaian kinerja itu sendiri. Selain itu juga, penilaian kinerja yang tidak tepat akan berdampak pada penurunan prestasi kerja dan menciptakan kondisi kerja yang tidak 
menyenangkan.

Moeheriono (2009) mengemukakan bahwa kompetensi dapat digunakan sebagai sistem dasar penilaian dan pengembangan karyawan karena sistem ini mengidentifikasi kompetensi pekerjaan yang akurat. Melalui system ini dapat diketahui gap kompetensi sehingga diketahui hal yang perlu dikembangkan.

Peneliti mengatasi permasalahan diatas dengan menyusun alat dan panduan penilaian kinerja berbasis kompetensi yang bertujuan untuk meningkatkan obyektifitas penilaian, menyesuaikan penilaian kinerja dengan kebutuhan perusahaan dan memberikan feedback perbaikan bagi karyawan sehingga kepuasan karyawan terhadap penilaian kinerja dapat meningkat. Selain itu juga diharapkan rancangan penilaian kinerja berbasis kompetensi ini dapat diterima oleh manajemen.

Setiap jabatan memiliki beberapa kompetensi yang berbeda, maka dari itu penilaian kinerja tidak dapat dibuat sama untuk seluruh jabatan. keterbatasan waktu dan tenaga peneliti maka penelitian ini fokus pada pembuatan rancangan penilaian kinerja untuk bagian keuangan yang terpilih secara acak dari beberapa bagian lainnya dan berdasarkan pertimbangan manajemen bahwa jabatan kasir di keuangan ditentukan menjadi proyek khusus untuk penerapan sistem penilaian kinerja berbasis kompetensi.

Rivai dan Sagala (2009), mendefinisikan kinerja sebagai fungsi dari motivasi dan kemampuan. Kinerja merupakan perilaku nyata yang ditampilkan setiap orang sebagai prestasi kerja yang dihasilkan oleh karyawan sesuai dengan perannya dalam perusahaan.

Dessler (2008) mengemukakan bahwa penilaian prestasi kerja merupakan upaya untuk membandingkan prestasi aktual pegawai dengan prestasi kerja yang diharapkan darinya.

Manajemen RS. XXX mendefinisikan penilaian kinerja/penilaian prestasi kerja sebagai suatu evaluasi atas kinerja karyawan dalam satu periode tertentu yang dilakukan oleh atasan langsung dari karyawan, dimana penilaian tersebut menggambarkan hasil kinerja karyawan yang bersangkutan, dengan maksud untuk mengevaluasi produktifitas kerja karyawan dan memotivasi karyawan untuk selalu mencapai hasil kerja yang lebih baik secara terus menerus.

Kinerja karyawan tidak terlepas dari kompetensi yang dimiliki. Rivai dan Sagala (2009) merumuskan kompetensi sebagai karakteristik dasar individu yang berhubungan dengan unjuk kerja/kinerja yang terbaik atau kompetensi yang superior selain itu juga kompetensi didefinisikan sebagai kemampuan seseorang yang dapat terobservasi yang mencakup pengetahuan, keterampilan dan sikap dalam menyelesaikan suatu pekerjaan atau tugas sesuai dengan perform yang telah ditetapkan.

Spencer \& Spencer (1993) menyatakan bahwa kompetensi adalah karekteristik yang mendasari seseorang untuk dapat bekerja dengan efektif. Karakteristik yang mendasari ini dimiliki oleh karyawan yang berkinerja prima atau superior di tempat kerja. Syafrika, Rostiana \& Zamralita (2006) mengemukakan bahwa kompetensi mencakup tiga hal, yaitu:

1. Kompetensi merupakan kombinasi dari berbagai karakteristik individual dimana beberapa karakteristik dasar ini tergabung menjadi satu kesatuan kompetensi.

2. Kompetensi berkaitan dengan kinerja yang efektif atau superior sehingga diketahui bahwa kompetensi merupakan karakteristik yang tampil atau terlihat dalam bentuk kinerja dan bukan sekedar potensi yang dimiliki oleh individu.

3. Kompetensi merupakan karakteristik individual yang mampu membedakan karyawan yang memiliki kinerja superior dan yang tidak sehingga dari pengukuran kompetensi akan didapatkan orang-orang yang kompeten dan yang tidak kompeten dibidangnya.

Lucia (1999) menyatakan bahwa 
kompetensi dapat dibedakan menjadi dua macam, yaitu kompetensi inti dan kompetensi spesifik. Kompetensi inti adalah kompetensi yang dibutuhkan oleh semua anggota organisasi tanpa memandang level jabatan, sedangkan kompetensi spesifik adalah aspek-aspek unik yang harus dimiliki oleh para karyawan dalam menghasilkan kinerja superior pada pekerjaan atau kelompok pekerjaan tertentu saja.

Dua macam pendekatan yang bisa digunakan dalam penyusunan model kompetensi yang dikemukakan Lucia (1999) yaitu:

\section{Starting from scratch}

Metode penyusunan model kompetensi ini mencakup identifikasi jabatan, mengambil data, analisis data, validasi kemudian didapatkan model kompetensi. Metode ini membutuhkan waktu yang lama, namun hasilnya spesifik pada masing-masing jabatan.

2. Starting with a validated competency model Perbedaan utamanya terletak pada penggunaan model kompetensi yang sudah valid sebagai permulaannya. Metode ini menghemat waktu, namun kurang mampu mengidentifikasi kompetensi spesifik untuk masing-masing jabatan.

Berbagi pendekatan dapat digunakan dalam melakukan evaluasi atau penilaian kinerja karyawan. Salah satunya adalah penilaian kinerja berbasis kompetensi. Penilaian kinerja berbasis kompetensi adalah proses evaluasi secara sistematis terhadap karyawan untuk membandingkan kompetensi aktual karyawan dengan kompetensi jabatan atau kompetensi yang diharapkan dalam pencapaian sasaran perusahaan. Dalam penelitian ini penilaian kinerja berbasis kompetensi disusun menggunakan metode starting from scratch untuk mendapatkan kompetensi spesifik sedangkan untuk kompetensi inti menggunakan metode starting with a validates competency model yang telah dilakukan oleh konsultan. Kompetensi yang disusun kemudian dibuat tingkatan pengukuran atas penguasaan kompetensi sesuai tuntuntan jabatan. Tingkat pengukuran pencapaian kompetensi ini disebut Level Kompetensi atau sering disebut indikator perilaku. Palan (2007) penyusunan level kompetensi berdasarkan 5 tingkatan assessment yaitu:

1. Tingkat Novice menunjukkan orang baru, dapat melakukan pekerjaannya tetapi tidak bisa memenuhi standar dan memerlukan supervisi ketat

2. Tingkat Learner menunjukkan seorang pemula dan mampu melaksanakan tugasnya meskipun belum secara konsisten memenuhi standar yang disyaratkan dan membutuhkan supervisi yang sering.

3. Tingkat Proficient menunjukkan seseorang yang telah mempunyai pengalaman dan mampu melaksanakan pekerjaannya sesuai dengan standar yang dituntut secara konsisten dengan kadang-kadang perlu di supervise. Pada Tingkat ini orang mampu mengindikasikan bahwa orang tersebut bisa melakukan pekerjaan tanpa bantuan.

4. Tingkat Professional menunjukkan seseorang yang berpengalaman, dapat melakukan pekerjaan dan memenuhi syarat secara konsisten tanpa supervise apapun.

5. Tingkat Expert menunjukkan seseorang yang diakui sebagai ahli atas kemampuannya melakukan pekerjaan dengan standar yang tinggi secara mandiri dan seseorang yang dapat membimbing orang lain.

Perusahaan menggunakan penilaian kinerja sebagai langkah administratif dan pengembangan. Secara administratif, perusahaan dapat menjadikan penilaian kinerja sebagai standar di dalam membuat keputusan yang berkenaan dengan kompensasi, promosi, pemberhentian, pengurangan dan PHK. Penilaian kinerja bertujuan untuk pengembangan melalui cara upaya mengidentifikasi kekuatan, kelemahan yang harus ditingkatkan, perencanaan pengembangan serta pembinaan dan 
perencanaan karir. (Mathis \& Jackson, 2006).

Tujuan RS. XXX melaksanakan penilaian prestasi kerja pada karyawannya adalah untuk:

1. Meningkatkan produktifitas, mengembangkan ketrampilan dan kompetensi karyawan.

2. Mendorong motivasi kerja karyawan untuk mencapai yang terbaik.

3. Sebagai salah satu bahan untuk perencanaan pelatihan \& pengembangan SDM, pertimbangan promosi dan mutasi karyawan, Umpan Balik bagi sistem rekrutment, pemberian tunjangan akhir tahun dan sistem remunerasi lain.

Untuk dapat mengukur kinerja dengan akurat, penilaia kinerja yang baik memiliki beberpa kriteria. Rivai \& Basri (2005) dan Moeheriono (2009) mengemukakan bahwa penilaian kinerja yang baik harus memenuhi beberapa persyaratan sebagai berikut:

1. Relevance, yaitu ada kesesuaian antara penilaian dengan tujuan sistem penilaian.

2. Acceptability, yaitu dapat dinilai atau disepakati karyawan.

3. Reliability, yaitu faktor penilaian harus dapat dipercaya dan diukur karyawan secara nyata dan ukuran kinerja harus konsisten satu ukuran

4. Sensitivity, yaitu dapat membedakan kinerja baik atau yang buruk.

5. Practicality, mudah dipahami dan dapat diterapkan secara praktis dan kekurangan data tidak terlalu mengganggu.

\section{METODE PENELITIAN}

Penelitian ini dilakukan dengan metode kualitatif yang menggunakan pendekatan studi kasus. Penelitan dengan pendekatan studi kasus memungkinkan peneliti untuk melakukan penjelajahan secara mendalam melalui uraian dan penjelasan yang komprehensif, dengan sebanyak mungkin data mengenai subyek yang diteliti. (Mulyana, 2001).
Subjek dalam penelitian ini berjumlah 22 orang terdiri dari para pelaksana dan jajaran manajerial. Para pelaksana meliputi pemangku jabatan Kasir Rawat Jalan sebanyak 6 orang, Kasir Rawat Inap sebanyak 4 orang, Kasir Inkaso sebanyak 3 orang, dan Kasir Besar sebanyak 3 orang. Sedangkan termasuk jajaran manajerial adalah 1 orang Kepala Bagian Keuangan, 1 orang Officer In Charge (OIC) Finance, 1 orang Kepala Bagian Rekrutmen dan Pengembangan, 1 orang Officer In Charge (OIC) IR \& HR Admin, 1 orang Officer In Charge (OIC) HR Strategic, dan 1 orang HR \& GA Division Manager. Penelitian ini fokus pada pembuatan rancangan penilaian kinerja untuk bagian keuangan.

\section{Tahapan penyusunan Penilaian Kinerja berbasis kompetensi}

Penyusunan penilaian kinerja berbasis kompetensi dilakukan dengan menggabungkan langkah penyusunan kompetensi yang di kemukakan oleh Spencer (dalam Moeheriono, 2009) dan langkah pembuatan penilaian kinerja yang dikemukakan oleh Mondy dan Noe (1993).

Sebagaimana dijelaskan pada gambar 1 , proses penyusunan penilaian kinerja berbasis kompetensi dilakukan melalui beberapa tahap, yaitu

1. Penyusunan Analisa Jabatan

Penelitian diawali dengan melakukan analisis jabatan terhadap 4 jabatan, yaitu Kasir Rawat Jalan, Kasir Rawat Inap, Kasir Inkaso dan Kasir Besar. Analisis Jabatan dilakukan dengan menganalisis data uraian jabatan, menyebarkan Questioner kepada pemangku jabatan, setelah itu dilakukan wawancara terhadap pemegang jabatan, kepala bagian keuangan, dan OIC Finance, kemudian analisis jabatan di validasi oleh pemegang jabatan, Kepala Bagian Keuangan dan OIC Finance. 


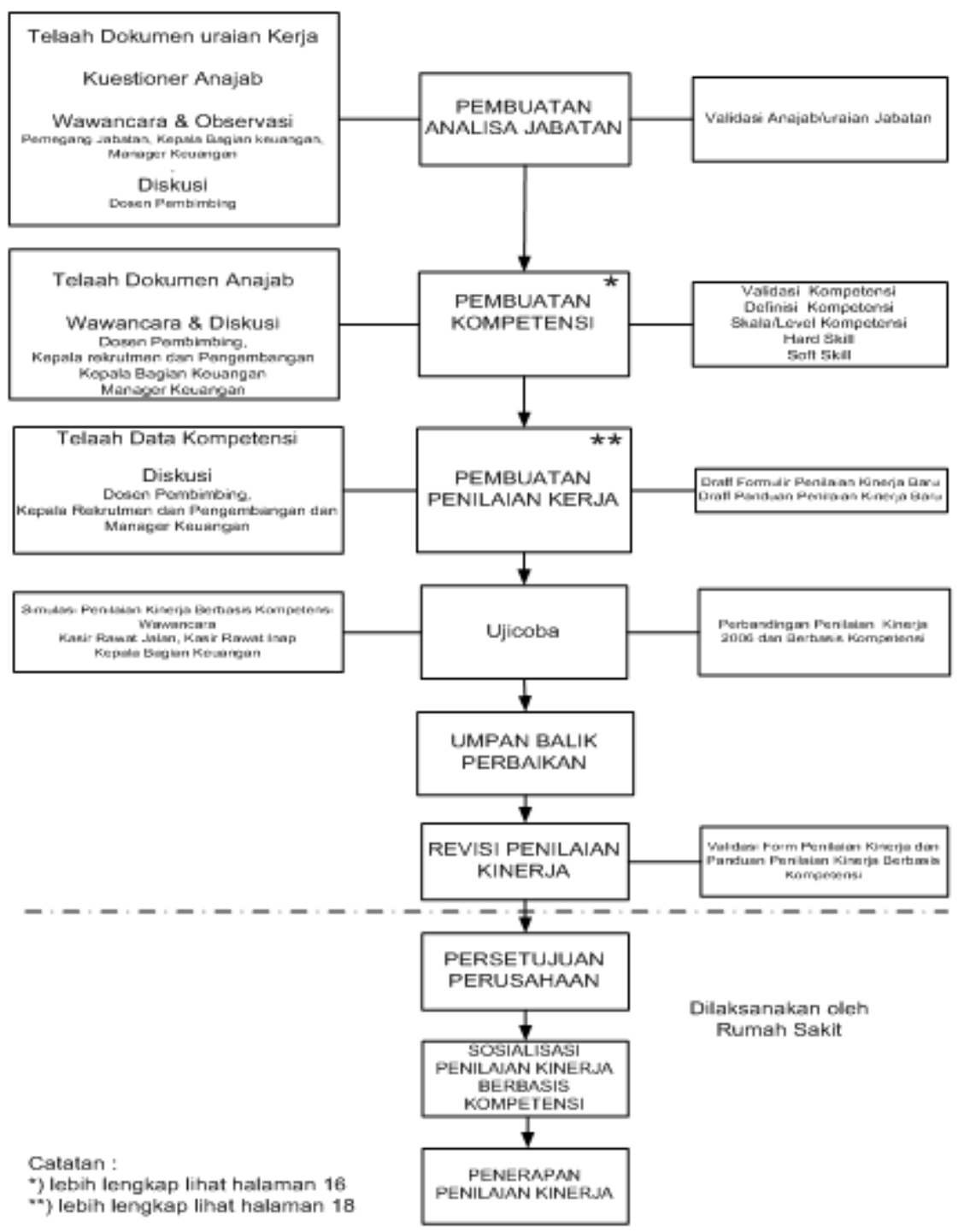

Gambar 1: Langkah Penelitian

2. Penyusunan Kompetensi

Kompetensi di kategorikan menjadi dua yaitu Kompetensi Inti dan Kompetensi Spesifik. Pembuatan Kompetensi Inti beserta definisinya telah dilaksanakan oleh pihak konsultan RS. XXX dan menetapkan 5 Kompetensi Inti yang terdiri dari Kompetensi Building Trust, Customer Focus, Strive For Excelent, Countinous Learning, dan Compelling Comunication. (DDI, 2009b)
Peneliti melakukan pembuatan Kompetensi Spesifik dengan menguraikan dan menganlisis anajab. Kompetensi dan definisi kemudian dikonsultasikan kepada OIC Finance, kepala bagian keuangan dan ahli.

Setelah didapatkan kompetensi, definisi dan levelnya kemudian dilakukan validasi. Validasi Level Kompetensi Inti dilakukan oleh Kepala Bagian Rekrutment dan Pengembangan, OIC IR \& HR Admin, 
Division Manager GA \& HR sedangkan Kompetensi spesifik divalidasi kepada Kepala Bagian Keuangan dan OIC Finance.

3. Pembuatan Penilaian Kinerja

Penilaian kinerja berbasis kompetensi ini mengunakan metode penilaian multi rater. Metode ini diajukan untuk mengatasi masalah subyektifitas penilaian yang disebabkan karena atasan tidak dapat mengawai kinerja bawahan setiap waktu.

Seperti yang dikemukakan Mathis dan Jackson (2006) bahwa penilaian oleh diri sendiri memaksa karyawan untuk memikirkan kelemahan dan kelebihan dirinya dan menetapkan tujuan peningkatan, penilaian oleh rekan sekerja berguna ketika para atasan yang tidak memiliki kesempatan untuk mengamati kinerja setiap karyawan, penilaian oleh atasan adalah penilaian yang paling memenuhi syarat untuk mengevaluasi kinerja karyawan secara realistis dan adil.

Appelbaum, Nadeau \& Cry (2009) mengemukakan bahwa metode penilaian kinerja multi rater efektif untuk mengukur kinerja dan untuk mendapatkan data kekuatan dan kelemahan karyawan selain itu penilaian dari rekan kerja lebih memotivasi daripada atasannya. Maka penilaian kinerja yang dilakukan oleh banyak penilai diharapkan menjadi solusi tepat.

Penilai pada penilaian kinerja berbasis kompetensi ini berjumlah 4 orang, Penilai 1 yaitu dirinya sendiri, Penilai ke 2 dan 3 yaitu rekan sejawatnya dan penilai ke 4 adalah atasannya langsung. Sedangkan persentase pembobotannya adalah $10 \%$ Penilai 1, 20\% Penilai 2 dan 3, dan $50 \%$ atasannya. Atasan mendapat persentase yang lebih besar dengan pertimbangan bahwa tanggung jawab terhadap proses penilaian masih merupakan tanggung jawab dari atasan.
Tahap selanjutnya adalah peneliti menentukan bobot kompetensi. Penilaian kinerja berbasis kompetensi untuk pelaksana/non manajerial telah ditentukan bobot Kompetensi Inti seluruhnya adalah sebesar 30\% dan Kompetensi Spesifik sebesar $70 \%$ hal ini berdasarkan pertimbangan bahwa para pelaksana lebih banyak melakukan pekerjaan-pekerjaan yang bersifat teknis dan rutin.

Pembobotan dilakukan untuk tiap jenis kompetensi menggunakan metode perbandingan berpasangan (Fuad \& Ahmad, 2009). Pembobotan untuk Kompetensi Inti dilakukan 3 orang yaitu oleh Kepala Bagian Rekrutmen dan Pengembangan, OIC IR \& HR admint dan Divison Manager GA \& HR, sedangkan untuk Kompetensi Spesifik dilakukan oleh 2 orang yaitu Kepala Bagian Keuangan dan OIC Finance.

Penilaian Kinerja Berbasis Kompetensi untuk jabatan kasir merupakan penilaian kinerja dengan metode multi rater dan BARS. Metode BARS adalah metode yang dinilai paling dapat dipercaya dan dipertangungjawabkan karena metode ini berdasarkan perilaku kerja yang dapat teramati secara nyata (Mondy, 2008). Komponen utama penilaian adalah kompetensi inti dan kompetensi spesifik. Selain itu penilaian kinerja berbasis kompetensi ini menyertakan kolom saran pengembangan, resume penilaian, grafik penilaian kompetensi, nilai total, kategori berdasarkan standar jabatan dan distribusi normal untuk melihat perbandingan prestasi karyawan yang dinilai dengan karyawan yang lainnya. Terdapat kolom kekuatan dan kelemahan karyawan untuk dapat membandingkan kelebihan dan kekurangan, terdapat hasil penilaian atasan dari atasan langsung dan karyawan yang dinilai sendiri, selain itu terdapat tanggal diskusi hasil 
penilaian yang diisi oleh karyawan guna memastikan bahwa hasil penilaian kinerja sudah didiskusikan dengan karyawan yang dinilai.

4. Uji Coba

Uji coba dilakukan terhadap 11 orang subyek dengan perincian sebagai berikut: 3 orang pemegang jabatan kasir rawat jalan, 3 orang pemegang jabatan kasir rawat inap, 1 orang kepala bagian keuangan, 1 orang OIC Finance, 1 orang OIC IR \& HR Admint, 1 orang OIC HR Strategic, dan 1 Orang Division Manager GA \& HR. 3 orang pemegang jabatan kasir rawat inap dan 3 orang pemegang jabatan kasir rawat jalan mencoba melakukan pengisian penilaian kinerja berbasis kompetensi dan penilaian kinerja 2006, sedangkan Kepala Bagian Keuangan, OIC Finance, OIC IR \& HR Admint, OIC HR Strategic, dan Division Manager GA \& HR melakukan pengisian penilaian kinerja berbasis Kompetensi, setelah itu subyek diwawancarai untuk dimintai pendapatnya tentang penilaian kinerja. Setelah dimintai pendapat, hasil di analis dan kemudian form penilaian kinerja berbasis kompetensi beserta panduannya direvisi dan divalidasi kepada: Kepala Bagian Keuangan, OIC Finance, OIC IR \& HR Admint, OIC HR Strategic dan Division Manager GA \& $H R$ dan selanjutnya diserahkan ke $H R D$ untuk diteruskan ke Manajemen untuk disosialisasikan.

5. Analisis Data

Teknik analisis data yang digunakan dalam penelitian ini adalah analisis kualitatif. Analisis Data dilakukan terhadap anajab, kuestioner, wawancara dan observasi. Analisis data pertamakali dilakukan untuk mereduksi dan mendapatkan data jabatan yang terkini (anajab). Tahap kedua analisis dilakukan untuk menemukan kompetensi Spesifik terhadap Jabatan Kasir rawat jalan, Kasir rawat inap, kasir inkaso dan Kasir besar. Analisis Terakhir dilakukan untuk mendapatkan gambaran tema perbandingan penilaian kinerja 2006 (penilaian kinerja yang digunakan sekarang) dengan penilaian kinerja berbasis kompetensi mengenai aspek relevansi, praktis, sensitivitas, reliabilitas, acceptabilitas, bahasa, obyektifitas, feedback dan panduan penilaian kinerja. Setelah itu dibuat rangkuman atas tema-tema tersebut.

\section{HASIL DAN PEMBAHASAN}

Setelah dilakukan ujicoba penilaian kinerja berbasis kompetensi maka didapat hasil terdapat perbedaan antara hasil penilaian kinerja sebelumnya yang digunakan pada tahun 2006 dan penilaian kinerja berbasis kompetensi. Penilaian kinerja berbasis kompentensi dipandang lebih relevan dalam mengukur kinerja dibandingkan dengan model sebelumnya, lebih praktis dan sensitive dalam mengukur kinerja. Penilaian kinerja berbasis kompetensi juga dipandang lebih konsisten (reliable) dalam mengukur kinerja dan lebih diterima karena lebih objektif dalam mengukur kinerja. Model ini juga memberikan kesempatan bagi karyawan untuk mendapat umpan balik lebih jelas atas kinerjnya. Hanya saja dari segi kepraktisan, model ini dinilai kurang praktis dari segi proses penilaian karena melibatkan beberapa penilai (multi rater). Selain itu penggunaan beberapa istilah asing juga dinilai menyulitkan bagi karyawan untuk memahami aspek-aspek penilaian. Perbandiangan antara model penilaian kinerja 2006 dengan penilaian kinerja berbasis kompetensi dapat diliat pada tabel berikut ini: 
Tabel 1. Perbandingan PK 2006 \& PK Berbasis Kompetensi

\begin{aligned} & \hline Aspek \multicolumn{1}{c}{ Penilaian Kinerja Sekarang (2006) } \\ & \hline Kurang Relevan, mengukur kinerja secara \\ & general, tidak sesuai dengan deskripsi \\ & jabatan dan kompetensi jabatan, tidak dapat \\ & digunakan untuk pengembangan dan \\ & pelatihan, kurang bisa sebagai dasar mutasi \\ & dan promosi. Saat ini digunakan untuk gaji \\ & dan bonus. \end{aligned}

Kurang Praktis, tidak dapat digunakan terpisah dari buku panduan. Satu Nilai mengandung banyak KPI dan batasan antara nilai tidak jelas sehingga sulit dinilai.

Kurang Sensitive, penentuan score penilaian pada kenyataannya dikarang sendiri karena buku panduan sulit dan kurang bisa mengukur kinerja baik dan buruk tiap aspek karena didalam satu nilai mengandung banyak KPI tidak hanya satu.

$\frac{\frac{8}{2}}{\frac{70}{81}}$

Kurang Reliabel, tiap penilai punya kategori dan cara mengisi penilaian yang berbeda satu sama lain. Batasan tidak jelas, standar tidak sama untuk stiap penilai.

Sudah disetujui dan diterapkan oleh manajemen selama 4 tahun, kurang diterima karyawan, para manager bagian HRD dan Keuangan.

sederhana, tetapi terlalu luas untuk dilakukan penilaian dan sering menimbulkan multitafsir.

Kurang Obyektif karena penilaian hanya dilakukan oleh kepala bagian, dan hasil penilaian dipaksakan untuk distribusi normal sehingga nilai tidak murni.

Hanya bisa untuk tujuan Administrasi yaitu untuk pemberian tunjangan dan bonus gaji. Tidak ada feedback untuk karya wan.

Panduan penilaian Tidak jelas terkesan membosankan karena lebih banyak uraiannya.

\section{Penilaian Kinerja Berbasiskan Kompetensi}

Relevan, berdasarkan kompetensi dan sesuai deskripsi jabatan sehingga bisa digunakan untuk bahan pertimbangan dalam pengembangan dan pelatihan karyawan, bisa digunakan bahan pertimbangan mutasi dan promosi serta penentuan gaji dan bonus.

Praktis, form sudah cukup jelas sehingga tidak perlu menggunakan buku panduan terus, KPInya satu sehingga lebih mudah menilai. Metode Multirater dinilai tidak praktis.

Cukup sensitive, Score penilaian sudah mampu membedakan dengan jelas antara nilai satu dengan nilai lain. Lebih detail antara nilai satu dengan lainnya. Scorenya lebih bisa dipertanggung jawabkan kepada kar yawan.

Cukup reliabel, Kategori nilai sudah ditetapkan dan dinilai lebih jelas, batasan nilai jelas bisa diamati secara nyata. Lebih konsisten dan detail.

Lebih diterima saat ini karena dapat mengetahui dengan jelas aspek yang diukur dan untuk mengetahui pengembangan dirinya secara lengkap dan dapat lebih dipertanggunjawabkan.

sulit dimengerti langsung tanpa memahami definisinya tenutama kompetensi inti, tetapi kategori penilaian lebih jelas.

Lebih Obyektif karena melibatkan penilai yang lebih banyak dan KPI penilaian jelas, ada catatan kritis. Nilai hasil penilaian tetap murni dan dikategorikan sesuai standar jabatan dan distribusi normal

Dapat digunakan untuk tujuan Administrasi dan Pengembangan. Selain untuk penentuan bonus gaji dan tunjangan dapat juga untuk pertimbangan pelatihan, mutasi promosi dll

Panduan penilaian lebih ringkas dan jelas

karena disertai contoh-contoh. 


\section{SIMPULAN}

Hasil penelitian menunjukkan bahwa penilaian kinerja berbasis kompetensi dinilai lebih obyektif daripada penilaian kinerja 2006, LEBIH reliable dan sensitive, lebih relevan dengan tujuan penilaian kinerja. Oleh karena itu penilaian kinerja berbasis kompetensi lebih diterima untuk diterapkan daripada penilaian kinerja 2006. Meskipun demikian, beberpa kelemahan dari penilaian kinerja berbasis kompetensi ini antara lain, dari segi bahasa. System ini masih banyak menggunkan istilah asing yang kurang familiar bagi karyawan sehingga tidak mudah dipahami oleh karyawan. Selain itu metode multi rater yang dinilai tidak praktis karena melibatkan lebih banyak orang dan banya proses. Oleh karena itu diusulkan dibuat software atau sistem IT untuk mengatasi kendala administratif. Meskipun demikian penilaian kinerja berbasis kompetensi untuk jabatan kasir telah diterima oleh manajemen dan dijadikan acuan dalam pembuatan penilaian kinerja bagi jabatan lainnya.

\section{DAFTAR PUSTAKA}

Appelbaum,S.H., Nadeau, D \& Cry, M. 2009. Performance evaluation in a matrix organization: a case study (part 3). Industrial and Comercial Training, Vol.41no.1,9-14

Armstrong, M. 2003. The Art Of HRD: Managing People, A Practical Guide for Line Manager. Alih Bahasa: Ramelan. Jakarta: Bhuana Ilmu Populer.

Bernadin, H. J., \& Russell, J. E. A. 1993. Human Resource Management: an experiential approach: McGraw-Hill Education - Europe McGraw-Hill Education.
Budiharto,S., \& Fahmie,A. 2002. Evaluasi Sistem Penilaian Kinerja Pegawai Administratif Tetap Universitas Islam Indonesia Yogyakarta. Jurnal Psikologika, Tahun VII No.13.

CHIU, Kai-ting., \& Michael. 2002. The Significance of a Value-driven Competency-based Performance Management System: Key Issues WithReference to Developments in the Hong Kong Police Force. Asia Journal Of Public Administration, Vol 24 No.2.235-256

Daya Dimensi Indonesia. 2009. Kompetensi: Kamus-Devinisi dan Perilaku yang Dapat Diamati RS. xxx.

Daya Dimensi Indonesia. 2009. Laporan Penyusunan Kompetensi Inti dan Kompetensi Rumpun Jabatan $R S . x x x$

Dessler, G. (2008). Manajemen Sumber Daya Manusia Jilid 1(ed 10). Jakarta: Penerbit Indeks.

Fuad, N., \& Ahmad, G. 2009. Integrated Human Resouces Development:Berdasarkan Pendekatan CB-HRM, TB-HRM, CBT dan CPD. Jakarta: PT. Grasindo.

Gaspersz, V. (2007). Organizational Excellence: model strategic menuju world class quality company. Jakarta:PT.Gramedia Pustaka Utama.

Ingarianti,T.M., \& Yuwono,I.,Fajrianti. (2005). Performance Appraisal di PT. Otsuka Indonesia. Jurnal Psikodinamik. Vol 7 No.2.

Islam, Rafikul., \& Rasad, M. 2005. Employee Performance Evaluation By AHP: A Case Study.dISAHP. Jully 8-10. 